\title{
Cross-compatibility of the Parents as the Main Factor for Successful Olive Breeding Crosses
}

\author{
Aurora Díaz ${ }^{1,2}$ and Antonio Martín \\ Instituto de Agricultura Sostenible-CSIC, Alameda del Obispo s/n, 14080, Córdoba, Spain \\ Pilar Rallo \\ Departamento de Ciencias Agroforestales, University of Sevilla-EUITA, Ctra Utrera km 1, \\ 41013 Sevilla, Spain \\ Raúl De la Rosa \\ IFAPA, CICE, Junta de Andaluciá. Avda Menéndez Pidal s/n, 14080 Córdoba, Spain
}

\begin{abstract}
AdDitional INDEX words. Cross-pollination, intercompatibility, microsatellites, Olea europaea, paternity analysis
Abstract. Previous analyses of olive (Olea europaea L.) crosses have revealed an important degree of pollen contamination. For this reason, the authors tested the paternity of a set of progenies coming from crosses among different cultivars within the olive breeding program of Córdoba, Spain, using four polymorphic microsatellites. They found that the expected pollen sired $141(83.4 \%)$ of the 169 samples analyzed. The contamination rate was either almost total or almost null within each particular cross considered, not being comparable between different crosses. In a second experiment the authors evaluated the influence of several factors on the success of olive crosses, the type of isolation bag, the timing and number of pollinations, and the cross-compatibility of the parents in a multifactorial assay in 2003. They observed no differences in the type of pollination bag used or the number and timing of pollen additions when they analyzed 145 seeds. The main factor affecting the success of the crosses seems to be the intercompatibility among cultivars, because it had a significant influence on the rate of contamination. In the failed crosses, the authors clearly detected the contribution of more than one cultivar to the paternity. The results obtained here indicate that some knowledge of cross-compatibility relationships in olive is required to design crosses in olive breeding programs effectively. To achieve this objective, the progeny parentage analysis could be of great help because of the high level of pollen contamination found among those studied here.
\end{abstract}

Growers have obtained most of the current olive cultivars by empiric selection over centuries (León et al., 2005). Several breeding programs are now devoted to releasing new cultivars better adapted to the actual trends in olive growing in different Mediterranean countries, such as Israel (Lavee, 1990), Italy (Bellini, 1993; Fontanazza and Baldoni, 1990), or Spain (Rallo, 1995).

Having a reliable cross method is one of the first essential steps for the progress of any breeding program. In this sense, those crosses whose progeny have been actually fertilized by the expected pollen donor (the cultivar used as the father during the crosses) are successful. Olive is a wind-pollinated species in which adding pollen to bagged branches of the maternal parent has been the usual cross protocol in breeding programs (Bellini, 1993; Fontanazza and Baldoni, 1990; Lavee, 1990; Rallo, 1995). Several authors have tried cloth and paper bags in previous experiments, obtaining higher fruit set in those branches isolated with the latter (Griggs et al., 1975). However, in all cases, they have only measured the

\footnotetext{
Received for publication 11 Mar. 2007. Accepted for publication 12 July 2007. We are grateful to Junta de Andalucía and the CAO00-018-C7-1 project of the Spanish Ministry of Agriculture, Food and Fisheries for the funding of this research.

We thank the World Olive Germplasm Bank of IFAPA “Alameda del Obispo" (Córdoba) and the Cultivar Collection of IFAPA "Venta del Llano" (Jaén), both in Spain, for the facilities provided. We thank Dr. Hava Rapoport for the helpful suggestions and critical revision of the manuscript.

${ }^{1}$ Present address: Diversity Genomics Group, NIAB, Huntingdon Road, Cambridge CB3 OLE (UK).

${ }^{2}$ Corresponding author. E-mail: qe2dibea@uco.es.
}

pollination effectiveness of the breeding crosses by the fruit set obtained, without considering that this can be the result of fertilization by different cultivars. So, we consider necessary the use of molecular markers in paternity tests to evaluate the success of the pollinations performed.

Different researchers have undertaken similar methodologies based on the measure of the fruit set to determine adequate pollen donors of certain olive cultivars (Morettini et al., 1972; Moutier, 2002), and in some cases they have complemented the studies with pollen tube growth tests (Cuevas and Polito, 1997; Wu et al., 2002). Nevertheless, the results were not always consistent (Lavee et al., 2002), because the data coming from different years allow one to classify the same pair of cultivars as cross-compatible and cross-incompatible.

Simple sequence repeats (SSRs), or microsatellites, are increasingly becoming the markers of choice for paternity analysis in plants, because they now offer an easy and reliable way to test the paternity of seeds and seedlings by checking the presence of parental alleles in the descendants (MorandPrieur et al., 2003; Nishizawa et al., 2005). Their codominant inheritance and high polymorphism make it possible to obtain high combined parentage exclusion probability values with a relatively low number of hypervariable loci (Díaz et al., 2006; Isagi et al., 2004). Several authors have used this technique in olive to examine the paternity of seedlings (De la Rosa et al., 2004) and even of ungerminated seeds (Díaz et al., 2006; Mookerjee et al., 2005). In fact, some of these studies have revealed a high occurrence of contamination with undesirable pollen among the progeny of both controlled self- and cross-pollinations in olive (De la Rosa et al., 2004; Díaz et al., 
2006). Furthermore, those findings have avoided coming to wrong conclusions about the male parent effect on the length of the juvenile period (Santos-Antunes et al., 2005) and on several agronomic characteristics (León et al., 2004a, b) in studies performed in the olive breeding program of Córdoba, Spain, because they have revealed that in some cases the real paternity is not the expected one.

The purpose of this research was to determine the impact of the type of pollination bag, the number and timing of pollen applications, and the cultivars used as parents on fertilization success in olive. For this, we tested the paternity of olive seeds using microsatellite markers.

\section{Materials and Methods}

Paternity testing in the routine breeding program of Сórdoba. We tested the paternity of the offspring of eight olive crosses made using six different cultivars from the breeding program of Córdoba (Table 1). We made the crosses in two different locations in southern Spain: at the World Olive Germplasm Bank of the Instituto Andaluz de Investigación y Formación Agraria, Pesquera, Alimentaria y de la Producción Ecológica (IFAPA) "Alameda del Obispo" (Córdoba) during 2000 and 2002, and at the cultivar collection of IFAPA "Venta del Llano" (Mengíbar, Jaén) in 2001.

We carried out the crosses using the two types of bags described later. We collected the pollen from paternal trees located in the World Olive Germplasm Bank and stored it at $-20{ }^{\circ} \mathrm{C}$ until its utilization. We determined pollen viability before use by optical microscopy, using acetic carmine and also by observing the pollen tube length after its germination during 24 to $48 \mathrm{~h}$ at $25^{\circ} \mathrm{C}$ in a solution consisting of $10 \%$ sucrose, $0.01 \%$ boric acid, and $10 \mathrm{mg} \cdot \mathrm{L}^{-1}$ tetracycline (Fernández-Escobar et al., 1983). We mixed the pollen with six parts of talc to increase its volume and then we sprayed it three times every $2 \mathrm{~d}$ onto the maternal bagged branches, as done in previous experiments (De la Rosa et al., 2004; Díaz, 2005). In all cases, we performed two replicates, choosing two maternal trees per cultivar in each cross.

STUDY OF FACTORS AFFECTING CROSS-POLLINATION SUCCESS. To test the influence of different factors on the success of olive crosses, we performed a pollination assay in the World Olive Germplasm Bank during 2003. We bag isolated the flowering branches of the maternal tree well before anthesis [with buds in DII phenological stage: the corolla size becoming larger than the calyx size (Tous and Romero, 1993)] to avoid any contact with airborne pollen. The bagged shoots bore 144 inflorescences on average. We devised a multifactorial design for studying the effect of the following three factors on the same bagged shoot (Table 2) and, as done previously, two replicates (in two different mother trees of the same cultivar) were made:

1. Pollination bag material. We investigated the influence of two types of branch isolation bagging material: doubleplastic perforated (1-mm-diameter holes) and Tyvek (DuPont, Wilmington, DE) (Del Río and Caballero, 1999; Smith and Mehlenbacher, 1994). Researchers have previously used both of them in olive controlled pollinations within the aforementioned breeding program in Córdoba.

2. Number and timing of pollen additions. We carried out three different pollination methodologies: a single pollination just before anthesis $(\mathrm{P} 1)$; three pollinations, one every $2 \mathrm{~d}$, starting

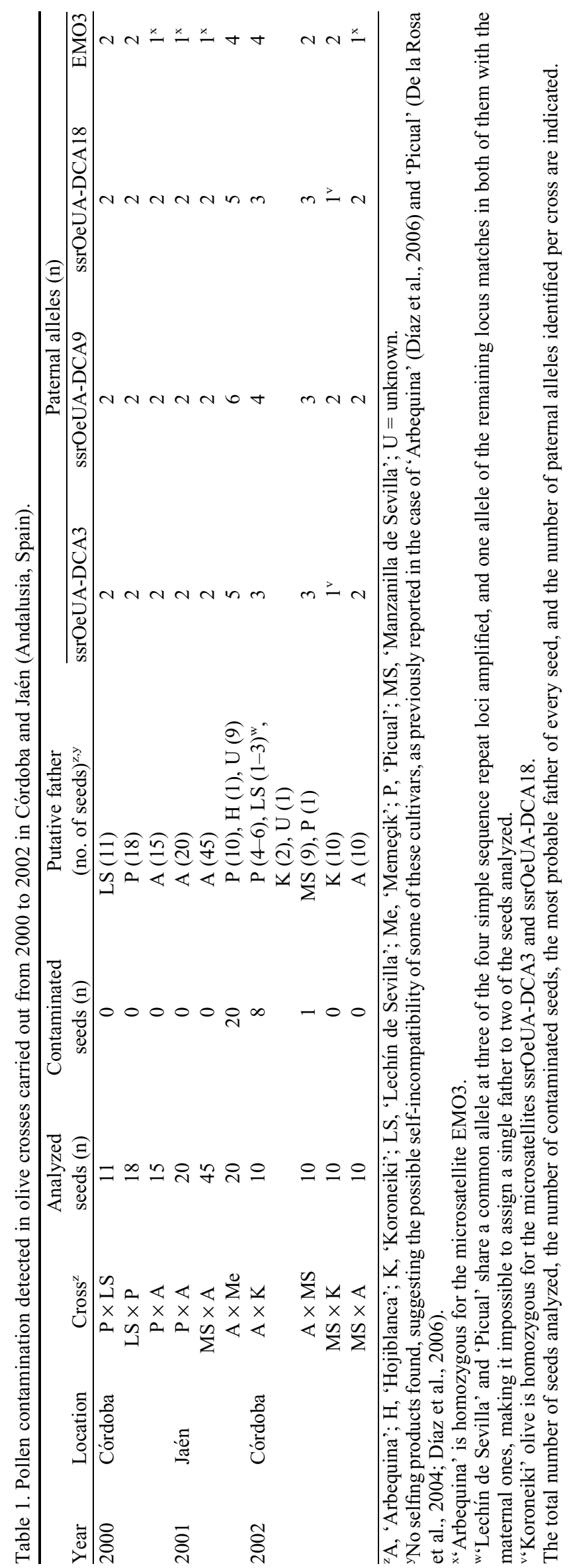




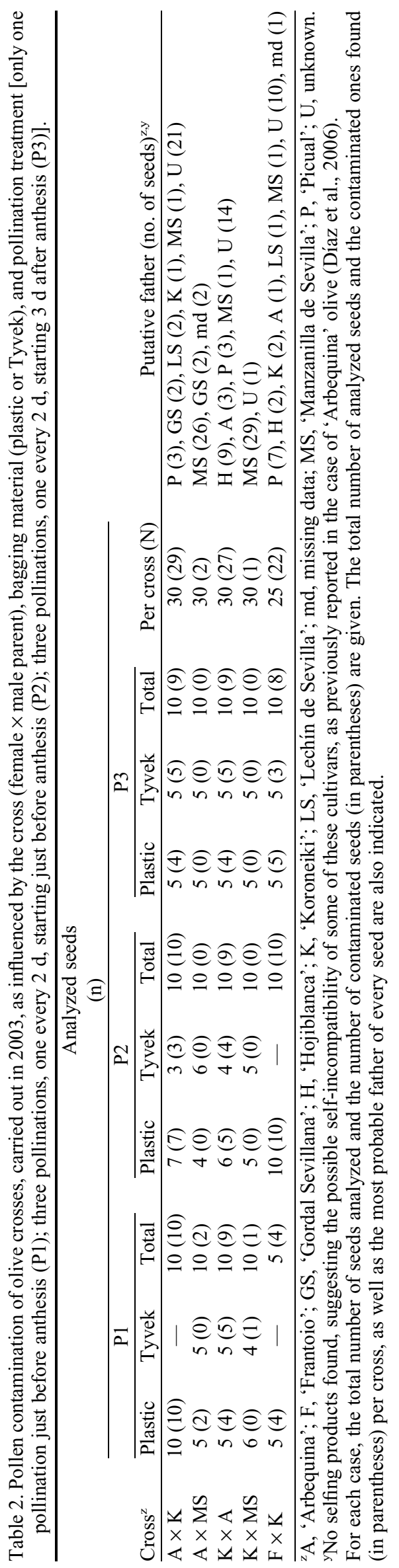

just before anthesis (P2); and three pollinations, one every $2 \mathrm{~d}$, starting $3 \mathrm{~d}$ after anthesis (P3).

3. Cross-compatibility between cultivars. We carried out five different cross combinations of 'Arbequina', 'Frantoio', 'Koroneiki', and 'Manzanilla de Sevilla' olive. We were interested in testing one cross that had previously worked well ('Arbequina' $\times$ 'Manzanilla de Sevilla'), and another in which we had detected a high pollen contamination rate ('Arbequina' $\times$ 'Koroneiki'). Additionally, all these cultivars show very interesting characteristics from a breeding point of view.

We selected a total of 30 seeds per cross for the paternity tests, 10 per treatment, five from every one of the two types of bags (Table 2), when available.

DNA ISOLATION FROM OLIVE OFFSPRING AND MICROSATELLITE AMPLification. We used two different DNA extraction approaches. For the progenies from the Córdoba routine breeding program, we germinated the seeds and isolated the DNA from leaves of the olive seedlings according to Murray and Thompson (1980) with slight modifications (De la Rosa et al., 2002). In the pollination experiment, we extracted the DNA directly from uncoated seeds as described by Díaz et al. (2006). We performed the DNA extractions using the DNeasy Plant Mini kit (Qiagen, Valencia, CA) and followed the supplier's instructions. We collected a total of 314 samples (one seed per fruit) for DNA isolation and amplification (Tables 1 and 2).

We chose a set of four olive microsatellites with great informative potential (high polymorphism) and proved amplification efficiency (De la Rosa et al., 2004; Díaz et al., 2006) - ssrOeUA-DCA3, ssrOeUA-DCA9, ssrOeUA-DCA18 (Sefc et al., 2000), and EMO3 (De la Rosa et al., 2002) - for the paternity analyses.

We amplified the DNA by polymerase chain reaction (PCR) in $15-\mu \mathrm{L}$ volume solutions with $15 \mathrm{~mm}$ Tris- $\mathrm{HCl}(\mathrm{pH}$ 8.0), $50 \mathrm{~mm} \mathrm{KCl}, 2.5 \mathrm{~mm} \mathrm{MgCl} 2,0.25 \mathrm{~mm}$ of each deoxyribonucleotide triphosphate (dNTP), $0.2 \mu \mathrm{M}$ of forward (fluorescently labeled) and reverse primers, $1 \mathrm{U}$ AmpliTaq-Gold polymerase (Applied Biosystems, Foster City, CA), and $15 \mathrm{ng}$ genomic DNA template. We performed all the reactions in a Gene Amp PCR system 9600 (Applied Biosystems) under the following profile: $11-\mathrm{min}$ initial denaturation step at $94{ }^{\circ} \mathrm{C}$, 35 cycles of $30 \mathrm{~s}$ at $94{ }^{\circ} \mathrm{C}, 45 \mathrm{~s}$ at the annealing temperature reported by the previous authors (De la Rosa et al., 2002; Sefc et al., 2000), 2 min at $72{ }^{\circ} \mathrm{C}$, with a final extension step of $7 \mathrm{~min}$ at $72{ }^{\circ} \mathrm{C}$. We diluted the amplicons 5 - to 20 -fold before analysis on an ABI 310 (Applied Biosystems) automatic sequencer running GeneScan software (version 3.7; Applied Biosystems).

We always confirmed the maternal allelic contribution and, when pollen contamination was detected, we inferred the putative male parent of each progeny by removing the maternal alleles from the complete genotype at the four microsatellites used, thanks to the availability of previous genotyping data (De la Rosa et al., 2004; Díaz, 2005; Rallo, 2001). The paternity assignment was made by eye and only when all paternal alleles for the four markers matched the putative father.

\section{Results and Discussion}

CONTROLled CROSS-POLlination Within a ROUTINE BREEDING PROGRAM. We were able to discriminate between seeds produced by the hand pollination performed and those coming from the fertilization by undesirable pollen thanks 
to the high combined parentage exclusion probability value $(0.92)$ provided by the four microsatellites used here and in a previous study (Díaz et al., 2006). We analyzed the paternity of 169 seedlings coming from eight different crosses performed in 3 different years within the Córdoba breeding program (Table 1). We found that the expected pollen sired $141(83.4 \%)$ of the 169 samples analyzed. The contamination rate was not comparable between all crosses. Quite the opposite, the contamination was either almost total or almost null within every cross (Table 1 ). We confirmed the expected parents for seedlings coming from the crosses 'Manzanilla de Sevilla' $x$ 'Arbequina', 'Picual' $\times$ 'Lechín de Sevilla' and their reciprocal ones, and 'Picual' $\times$ 'Arbequina' and 'Manzanilla de Sevilla' $\times$ 'Koroneiki'. In the case of the crosses 'Arbequina' $\times$ 'Koroneiki' and 'Arbequina' $\times$ 'Memeçik', the level of contamination with foreign pollen was nearly total. We could identify 'Picual' olive as being the primary pollen donor in these contaminated crosses, therefore confirming previously reported results (De la Rosa et al., 2004; Díaz et al., 2006). We could not determine the pollen donor in some cases $(5.9 \%)$. This is not unusual because the genotypic profile for the four SSRs used here was not available for many cultivars grown in the two previously mentioned germplasm collections. In light of these results, we designed an experiment aimed at figuring out the determining factors for obtaining pure offspring from olive crosses.

Study OF FACTORS AFFECTING CROSS-POLlinAtion SUCCESS. Pollen from a different source to that added to the bagged shoots sired a total of $81(55.9 \%)$ of 145 seeds analyzed in this experiment (Table 2). As noted previously, we could not determine the pollen donor in some cases $(22.1 \%)$, although the paternal alleles identified in those seeds (more than two per marker) clearly suggest the contribution of more than one cultivar to their paternity. The distribution of those contaminated seeds among crosses is indicative of the main factor affecting the success of the fertilizations, as shown here:

1. Pollination bag material. Although we expected the amount of pollen able to gain access to bagged flowers to be higher when we used perforated plastic bags, neither the contamination ratio with undesirable pollen within each cross (Table 2) nor the fruit set measured inside both types of bags (data not shown) were related to the type of bag used in pollination tests. So, the paternity analyses have demonstrated the permeability of both materials to airborne pollen. Interestingly, this lack of isolation did not hamper successful fertilizations in certain cultivar combinations. Transparent plastic bags offer the possibility of monitoring floral and fruit development and, therefore, should be selected if this information is considered of interest.
2. Number and timing of the pollen additions. We observed no differences in the contamination rate between the fruit obtained in the three treatments carried out during 2003 (Table 2), although in the first two (P1 and P2) we started pollination just before anthesis, and in the last one (P3) we started pollination $3 \mathrm{~d}$ after anthesis. Similarly, we have not detected any possible influence of the number of pollinations, one in treatment $\mathrm{P} 1$ and three in the remaining treatments $\mathrm{P} 2$ and $\mathrm{P} 3$, on the effectiveness of cross methods. This indicates that only one pollination just before anthesis could be sufficient to have a pure progeny. Because pollen is quite laborious to collect and it is obtained in small quantities, protocol P1 could represent important time and effort savings.

3. Cross-compatibility between cultivars. We observed noticeable differences in fertilization success by the pollen supplied. The high degree of contamination of some crosses and the purity of others indicate a strong influence of the cultivar combination on the effectiveness of the pollinations independent of the pollination bag material used or the number and timing of the pollen additions (Table 2). Interestingly, two of the combinations with the highest levels of contamination with undesirable pollen are reciprocal ('Arbequina' $\times$ 'Koroneiki' and vice versa). De la Rosa et al. (2004) obtained similar results for the cultivar combination 'Arbequina'-'Zaity' in previous experiments. These results are consistent with those obtained in the preliminary assays (Table 1). As in that case, we identified predominant pollen donors when we used particular cultivars as the maternal parent.

A multifactorial analysis of variance revealed that crosscompatibility between cultivars was the only factor showing a significant influence on the rate of contamination $(\mathrm{F}=67.58$, $P<0.001)$. According to these results, intercompatibility between cultivars acting as parents seems to be the most important factor among those studied to achieve success in obtaining desired progeny. The type of bag, and the timing and number of pollinations do not seem to be crucial factors. Furthermore, we did not observe spontaneous self-pollinations, even when we carried out the pollen additions after anthesis, which is in agreement with a previous study about self-incompatibility in olive (Díaz et al., 2006).

Cross-Compatibility Relationships. The cultivars considered here seem to exhibit reciprocal intercompatibility relationships; that is, a certain cultivar pair behaves in the same way independently of which cultivar acts as the male or the female parent (Table 3). This suggests that a gametophytic incompatibility system might be acting in olive (Mookerjee et al., 2005; Sedgley, 1994). In fact, olive flowers have a wet stigma (Ciampolini et al., 1983) and generally binucleate pollen (Bradley and Griggs, 1963), which are considered to be two signs of gametophytic self-incompatibility (Sedgley, 1994).

Table 3. Compatibility relationships [cross-compatible (c), cross-incompatible (i)] between the olive cultivars used in the present work, as revealed by paternity analysis.

\begin{tabular}{|c|c|c|c|c|c|c|c|}
\hline \multirow[b]{2}{*}{ Female } & \multicolumn{7}{|c|}{ Male } \\
\hline & Arbequina & Frantoio & Koroneiki & Lechín de Sevilla & Manzanilla de Sevilla & Memeçik & Picual \\
\hline Arbequina & & & $\mathrm{i}$ & & $\mathrm{c}$ & $\mathrm{i}$ & \\
\hline Frantoio & & & $\mathrm{i}$ & & & & \\
\hline Lechín de Sevilla & & & & & & & $\mathrm{c}$ \\
\hline $\begin{array}{l}\text { Manzanilla de Sevilla } \\
\text { Memeçik }\end{array}$ & $\mathrm{c}$ & & $\mathrm{c}$ & & & & \\
\hline
\end{tabular}


In this sense, we always obtained pure progenies from crosses 'Picual' $\times$ 'Lechín de Sevilla', 'Manzanilla de Sevilla' $\times$ 'Arbequina' and 'Manzanilla de Sevilla' $\times$ 'Koroneiki', and the reciprocal ones. On the contrary, we found that the contamination was almost total when we tested the progeny from the cross 'Arbequina' $\times$ 'Koroneiki' and the reciprocal one. Additionally, we can classify the pair 'Picual' $\times$ 'Arbequina' olive as cross-compatible, whereas 'Arbequina' $\times$ 'Memeçik' and 'Frantoio' $\times$ 'Koroneiki' olive are crossincompatible (data corresponding to the reciprocal crosses are not available).

The cultivar associations obtained (Table 3) are in accordance with previous self- and cross-pollination results (De la Rosa et al., 2004; Díaz, 2005; Díaz et al., 2006) and with the predominant pollen donors identified in contaminated crosses here and in previous studies. As an example, 'Manzanilla de Sevilla' was one of the main sources of contaminant pollen when 'Arbequina' was used as the mother in self-pollination tests. So, the good results derived from the cross 'Arbequina' $\times$ 'Manzanilla de Sevilla' are not surprising (Tables 1 and 2). This contradicts a previous report made when testing only the fruit set, in which the author considered 'Arbequina' olive as a bad pollinator of 'Manzanilla de Sevilla' olive (Moutier, 2002). Similarly, 'Arbequina' olive appears as one of the most frequent pollen donors in 'Picual' tree self-pollinations in the previous studies (De la Rosa et al., 2004; Díaz et al., 2006) and, consequently, the cross 'Picual' $\times$ 'Arbequina' also worked correctly (Table 1).

The cross-compatibility information (Table 3 ) could also be useful in those cases in which growers require the presence of pollen donors (Moorkerjee et al., 2005), such as in areas where they are replacing the existing diversity of cultivars by an increasing homogeneity of high productive ones (Junta de Andalucía, 2002) or in countries where olive is not a native tree and they have imported a few cultivars from traditional olive-growing areas. However, in the current study, we established the cross-compatibility relationships between cultivars under artificial conditions (controlled pollinations), so breeders and growers must verify the overlapping of both parental cultivar bloom periods in particular locations and environments to guarantee cross-compatibility in situ. According to the bloom periods reported by Barranco and Rallo (2005) in research carried out during 6 years in Córdoba (Spain), the cultivar combinations 'Arbequina'-'Manzanilla de Sevilla' and 'Picual'-'Lechín de Sevilla' (in both reciprocal crosses) and 'Picual' $\times$ 'Arbequina' should also be compatible in field conditions because their blooms occur simultaneously (data on 'Koroneiki' olive bloom period are not available).

The average temperature and relative humidity during the blooming period (April and May) in the locations in which we carried out the crosses were $17.5{ }^{\circ} \mathrm{C}$ and $67.3 \%$ in 2000 , $17.0^{\circ} \mathrm{C}$ and $60.1 \%$ in $2001,16.7^{\circ} \mathrm{C}$ and $64.2 \%$ in 2002 , and $18.6{ }^{\circ} \mathrm{C}$ and $59.5 \%$ in 2003 respectively. Even though the climatic conditions are supposed to affect the compatibility behavior of the olive cultivars (Bradley and Griggs, 1963), we have obtained consistent results in all the crosses made in two different years ('Picual' $x$ 'Arbequina', 'Manzanilla de Sevilla' $\times$ 'Arbequina', 'Arbequina' $\times$ 'Koroneiki', and 'Arbequina' $x$ 'Manzanilla de Sevilla'; Tables 1 and 2). These results agree with those obtained in a previous study in which the selfincompatibility of 'Arbequina' and 'Picual' olive revealed invariable in different environments (Díaz et al., 2006).
In short, cross-compatibility relationships are revealed as being a vital factor in the success of olive crosses and, therefore, of breeding programs. This information is also of great interest in the design of new plantations. Microsatellite markers could be very useful to confirm future results about the genetic control of the compatibility system acting in olive, which is still unknown.

\section{Literature Cited}

Barranco, D. and L. Rallo. 2005. Épocas de floración y maduración, p. 281-292. In: L. Rallo, D. Barranco, J.M. Caballero, C. Del Río, A. Martín, J. Tous, and I. Trujillo (eds.). Variedades de olivo en España, Vol. II. Variabilidad y selección. Junta de Andalucía, MAPA, and Ediciones Mundi-Prensa, Madrid, Spain.

Bellini, E. 1993. Variabilidad genética y heredabilidad de algunos caracteres en las plantas de semillas de olivo obtenidas por cruzamiento. Olivae 49:21-34.

Bradley, M.V. and W.H. Griggs. 1963. Morphological evidence of incompatibility in Olea europaea L. Phytomorphology 13:141-156.

Ciampolini, F., M. Cresti, and R.N. Kapil. 1983. Fine ultrastructural and cytochemical characteristics of style and stigma in olive. Caryologia 36:211-230.

Cuevas, J. and V. Polito. 1997. Compatibility relationships in 'Manzanillo' olive. HortScience 32:1056-1058.

De la Rosa, R., C.M. James, and K.R. Tobutt. 2002. Isolation and characterization of polymorphic microsatellites in olive (Olea europaea L.) and their transferability to other genera in the Oleaceae. Mol. Ecol. Notes 2:265-267.

De la Rosa, R., C.M. James, and K.R. Tobutt. 2004. Using microsatellites for paternity testing in olive progenies. HortScience 39:351-354

Del Río, C. and J. Caballero. 1999. A new bag for olive pollination studies. Acta Hort. 474:233-235.

Díaz, A. 2005. Desarrollo y caracterización de nuevos microsatélites y SNPs y aplicación en la mejora genética del olivo (Olea europaea L.), Córdoba Univ, Córdoba, Spain. PhD Diss.

Díaz, A., A. Martín, P. Rallo, D. Barranco, and R. De la Rosa. 2006. Self-incompatibility of 'Arbequina' and 'Picual' olive assessed by SSR markers. J. Amer. Soc. Hort. Sci. 131:250-255.

Fernández-Escobar, R., G. Gómez-Valledor, and L. Rallo. 1983. Influence of pistil extract and temperature on in vitro pollen germination and pollen tube growth of olive cultivars. J. Hort. Sci. 58:219-227.

Fontanazza, G. and L. Baldoni. 1990. Propuesta de un programa de mejora genética del olivo. Olivae 34:32-40.

Griggs, W.H., H.T. Hartmann, M.V. Bradley, B.T. Iwakiri, and J.E. Whisler. 1975. Olive pollination in California. California Agr. Expt. Sta. Bul. 869:1-50.

Isagi, Y., T. Kanazashi, W. Suzuki, H. Tanaka, and T. Abe. 2004. Pollination patterns in Magnolia obovata revealed by microsatellite paternity analysis. Int. J. Plant Sci. 165:1047-1053.

Junta de Andalucía. 2002. El olivar andaluz. Junta de Andalucía, Seville, Spain.

Lavee, S. 1990. Aims, methods, and advances in breeding of new olive (Olea europaea L.) cultivars. Acta Hort. 286:23-36.

Lavee, S., J. Taryan, J. Levin, and A. Haskal. 2002. Importancia de la polinización cruzada en distintas variedades de olivo cultivadas en olivares intensivos de regadío. Olivae 91:25-36.

León, L., L.M. Martín, and L. Rallo. 2004a. Phenotypic correlations among agronomic traits in olive progenies. J. Amer. Soc. Hort. Sci. 129:271-276.

León, L., L.M. Martín, and L. Rallo. 2004b. Repeatability and minimum selection time for fatty acid composition in olive progenies. HortScience 39:477-480.

León, L., A. Santos-Antunes, L.M. Martín, A. Garrido, and L. Rallo. 2005. Obtención de nuevas variedades por cruzamientos, p. 407-420. In: L. Rallo, D. Barranco, J. Caballero, A. Martín, C. Del Río, J. Tous, 
and I. Trujillo (eds.). Variedades de olivo en España, Vol. III. Mejora genética y biotecnología. Junta de Andalucía, MAPA, and Ediciones Mundi-Prensa, Madrid, Spain.

Mookerjee, S., J. Guerin, G. Collins, C. Ford, and M. Sedgley. 2005. Paternity analysis using microsatellite markers to identify pollen donors in an olive grove. Theor. Appl. Genet. 111:1174-1182.

Morand-Prieur, M.E., C. Raquin, J.A. Shykoff, and N. FrascariaLacoste. 2003. Males outcompete hermaphrodites for seed siring success in controlled crosses in the polygamous Fraxinus excelsior (Oleaceae). Amer. J. Bot. 90:949-953.

Morettini, A., G. Bini, and E. Bellini. 1972. The performance of several French and Spanish table olive cultivars in the Maremma district of Tuscany. Rivista della Ortoflorofrutticoltura Italiana 56:3-19.

Moutier, N. 2002. Self-fertility and inter-compatibilities of sixteen olive varieties. Acta Hort. 586:209-212.

Murray, M.G. and W.F. Thompson. 1980. Rapid isolation of highmolecular-weight DNA. Nucl. Acids Res. 8:4321-4325.

Nishizawa, T., Y. Watano, E. Kinoshita, T. Wahara, and K. Ueda. 2005. Pollen movement in a natural population of Arisaema serratum (Araceae), a plant with a pitfall-trap flower pollination system. Amer. J. Bot. 92:1114-1123.

Rallo, L. 1995. Selección y mejora genética del olivo en España. Olivae 59:46-53.
Rallo, P. 2001. Desarrollo y aplicación de microsatélites en olivo (Olea europaea L.), Córdoba Univ, Córdoba, Spain. PhD Diss.

Santos-Antunes, A., L. León, R. De la Rosa, J. Alvarado, A. Mohedo, I. Trujillo, and L. Rallo. 2005. The length of the juvenile period in olive as influenced by vigor of the seedlings and the precocity of the parents. HortScience 40:1213-1215.

Sedgley, M. 1994. Self-incompatibility in woody horticultural species, p. 141-163. In: E.G. Williams, A.E. Clarke, and B.R. Knowx (eds.). Genetic control of self-incompatibility and reproductive development in flowering plants. Kluwer, Dordrecht, The Netherlands.

Sefc, K.M., M.S. Lopes, D. Mendonça, M. Rodrigues Dos Santos, M. Laimer Da Câmara Machado, and A. Da Câmara Machado. 2000. Identification of SSR loci in olive (Olea europaea) and their characterization in Italian and Iberian olive trees. Mol. Ecol. Notes 9:1171-1173.

Smith, D.C. and A. Mehlenbacher. 1994. Use of Tyvek housewrap for pollination bags in breeding hazelnut (Corylus avellana L.). HortScience 29:918.

Tous, J. and A. Romero. 1993. Variedades del olivo. Fundación "La Caixa,", Barcelona, Spain.

Wu, S.B., G. Collins, and M. Sedgley. 2002. Sexual compatibility within and between olive cultivars. J. Hort. Sci. Biotechnol. 77: $665-673$. 